\title{
Practices and Cultural Consumption among Tunisians School Youth
}

\author{
Fairouz Azaiez ${ }^{1,2}$ \\ Higher Institute of Sport and the Physical Education of Sfax (Tunisia). \\ Studies Group of Development and Social Environment (Faculty of Letters and Social Sciences of Sfax.
}

\begin{abstract}
The Tunisian habituation ability to the profound changes that affect with the same way all industrialized countries depends on the skills, qualifications and openness to the world. The Practices and cultural consumption of school youth are a major asset for social and economic development of modern Tunisia. The first studies on the culture was made by Tylor in 1871, who defined culture as the knowledge beliefs, arts, laws and customs acquired by man as a member of society. The time of the educated youth, characterized by behaviors and tastes to this class is associated with specific cultural practices and sociability. This study shows that leisure activities among sfaxians aged 15 to 25 years perfectly illustrate these characteristics. Indeed, being young and single mode promotes leisure outward. School youth reject practices leisure with sociability centered on family and develop a strong friendly sociability prefer reading novels and finally practice especially psychomotor sports games (predominantly female) and sociomotor (male-dominated).
\end{abstract}

Keywords: Youth, Leisure, Cultural Practices, Cultural Consumption

\section{Introduction}

The Tunisian habituation ability to the profound changes that affect with the same way all industrialized countries depends on the skills, qualifications and openness to the world. Who is better than young people with imagination, innovation and dynamism that they are known with (Derbaix \& Leheut, 2008). Indeed, young Tunisians today (representing 18.9\% of the total population with age from 15 to 25 years) are more and more mobile, free and independent than their elders, more sensitive to innovation and change of the world (Amri, 2007). They are also more open to cultural diversity. The Culture of our youth has become more and more expected and deployed than previous generations (Gauthier, Molgat \& St. Lawrence, 1999; Gauthier $\&$ Mercier, 1994).

The practices and cultural youth consumption is a major asset for social and economic development of modern Tunisia. Indeed, through their cultural practices, young people exhibit the edges of the culture and identity of the Tunisia's future. The first studies on the culture was made by lawyer Edward B. Tylor in 1871, he defined culture as the knowledge beliefs, arts, laws and customs acquired by man as a member of society. These studies have led to the functionalist theory that explained the relationship between the individual and the culture. According to Malikowski (1944), culture is a way to adapt to the natural environment in order to fulfill their needs. The presence of individuals in society expressed their reason to be. The culture plays a vital role in the social development of the individual, who is always the product of his culture. As against, the interactionist theory gives more importance to the role of the individual within the culture (Goffman, 1987; Schutz \& Luckmann, 1973). Rock (1969) adds the culture is a million little details about the way we think, feel and act in our daily lives. Finally, the cultural universe of youth "body of knowledge, tastes, and sufficiently homogeneous and stable cultural patterns to characterize the relationship to the culture of certain categories of people" (Donnat, 1998:339). Thus the word "culture" includes a plurality of sense (Hersent, 2003).

The study of different societies identified four functions of culture (Campeau, Sirois, 1993): The first is a function of adaptation culture allows the individual to cope with its environment by allocating a set of solutions to his survival problems (food, housing, etc.). The second is a function of communication. According Tea \& Hubert (1988), this is a principal function, thanks to it we can distinguish between different social groups themselves and the animal, according to their language and symbols. The third is an individual behavioral function that individuals adopt similar behaviors. In fact, when you know the culture of a people, we can reveal some of the individual behavior of its members. Finally, culture has an identification function (Oetting, \& Beauvais, 1991).The culture here ensures the unity of the group and allows each member of the company to identify its objects, values and beliefs.

Socialization is defined by (Rock, 1970) as the process by which human beings learn and internalize the social and cultural aspects of the environment, integrated into the structure of his personality under the influence of experience and significant social agents and then adapt to the social environment in which they must live. Once the child has acquired, through various forms of learning (strengthening, conditioning, 
observations or interaction with others), cultural heritage or "habitus" accrediting him to behave similarly to own (Bourdieu, 1979).

The Industrial Development as an entering the era of mechanical society has resulted an increased collective resources, productivity and increase of goods and services. Beck \& Edgar (2010) argue that we are in the midst of a transformation or transition from industrial to post-industrial society.This capitalization of cultural social and economic system, helped accelerate the transformation and the relative consumption and spending on health and recreation (Giddens 2007).Therefore, the majority of Tunisians live in monotony, routine and frustration of daily mechanized life, hence the need for distraction and entertainment through sports and physical activities. The development of technical knowledge will lead to the emergence of new models of the body on which building exercises and become possible and necessary (During, 1984; Detrez, 2002).

From these revaluation concepts of the body in our modern society, cultural practices continue to grow and diversify. They become a socio-cultural and economic reality (Pronovost, 2000). Leisure practices are not the result of free time enjoyment, satisfaction or rest daily tasks, but it is a time unproductive consumption (Baudrillard, 1970; Dumazedier 1988; Maresca, 2004, Salvador, 2001). Young people are so high consumers of cultural practices (Pasquier, 2004 Kaufman \& Gabler, 2004; Chéreau \& Lanlay, 2004). These changes in the lifestyles of young people are the first step in the conquest of autonomy and unpredictable (De Singly, 2006). Thus they develop an "expressive individualism" (Metton, 2004) in their values, they adopt behaviors and their tastes and also their own system of recognition. This youth's time or "present time" (Beaud, 1997) is associated with leisure practices and specific social skills and values such as pleasure, body desire, usability, development and self-transcendence (Gagnon et al, 1997; François, 2007).

Scientific studies show that cultural practices reveal social behaviors that differentiate girls and boys (David, 2011 and October, 2009; Donnat, 2005). The choice of activities reveals differentiations rather stereotypical gender (Bourdieu, 1998), girls tend to turn to the artistic activities and boys to sporting activities (October 2004 activities Garton\& Pratt, $1991 \mathrm{McGee,} \mathrm{Williams} \mathrm{et} \mathrm{al} \mathrm{.,} \mathrm{2006).} \mathrm{Although} \mathrm{the} \mathrm{effect} \mathrm{of} \mathrm{this} \mathrm{variable}$ under brand through time, it should be noted that many investigations still bind positively the fact of being a woman at the discretion of "legitimate culture" (Bihagen, \& Katz-Gerro al, 2000. Gerro-Katz, 1999, 2002; Kracman 1996; Callier, Hanquinet, \& al, 2012). According to Tavan (2003), the cultural practices of men and women are very similar, except for reading and the arts. Women practice less than men, attend less festive outings to sporting events, and adhere less to the new screen Culture (Callier, Hanquinet, et al., 2012). However, men favor the competition and the search for dominance, while women are focused more on cooperation and affiliation (Viira \& Raudsepp, 2000; Kindelberger, Le Floc'h et al, 2007). The identification models, the respective representations of femininity and masculinity result in sexual culture. The girls expressed rather in reference to the musical world (Monnot, 2009), while boys do more in relation to sport. On reading, girls show more pronounced taste than their male counterparts (October, 2011). Indeed, $41 \%$ of boys against girls $1 / 4$ only say they have read a book. As against, the boys scored significantly higher than girls in reading comics $(36 \%$ vs. $21 \%)$, scientific books (16\% vs. $8 \%$ ). As against the difference increases between the sexes when it comes to reading novels (girls $22 \%$ boys vs. 10\%) (Hersent 2004 Pasquier, 2005; Horellou-Lafarge \& Segre, 2003; Lartet-Geffard, 2005).Regarding the daily press, Lipani-Vaissade (2005) notes that young people have turned in recent years to the free press. Young people in 2004 were more than $16.7 \%$ of the readings national press against $23.7 \%$ in 1974 .

About the analysis of outputs, the massive penetration of digital technologies or "culture screens" (Monnat, 2009) has significantly altered the ratio of young people to culture. By cons, contrary to popular belief, the appropriation of this new medium of the Internet increases the time spent at home at the expense of outdoor activities, it reveals that its use characterizes developing a youth-oriented cultural life outside. Infact, youth is with excellence, the time of friendliness, time with friends and time buddies. This increased output represents a way for the young to assert themselves, to build their world outside the family and to forge an identity (Zaffran, 2010; Hamonic, 2003). Therefore, young people are more likely to prefer general cultural activities that permit them to leave their homes. Questioned on how sociability developed during their leisure, youth Rhinois Top (France) are $78.3 \%$ who reported to prefer activities that are practiced in the company of friends and / or friends rather than alone, as a couple or with Parents (Bauger, 2000). Girls show in particular a slightly more pronounced for the theater (12\% vs. $9 \%$ for boys), for writing (18\% vs. 9\%) interest, but mostly hang out with friends $(66 \%$ vs. $52 \%)$ (Hersent, 2004). Young people are also more likely to prefer in general leisure activities that permit them to leave their homes (91\% against $69 \%$ of the entire French population) (Donnat, 1998). Moreover, the only male-dominated cultural outings are jazz concerts and those of electronic music (techno.) and Rock, where women account for about a third of the public. Once the activity is framed it feminine, and boys "escape" structures (Détrez, Merkle et al, 2005.Guarcia\& Faure, 2005).To these traditional social cleavages, adds another division, one related to the social environment. Cultural practices are not torn to innate taste; they are not an expression of pure individual subjectivity. They come instead from social determinism: the role of individuals in social space has a decisive influence cultural practice (Bourdieu \& Passeron, 1964; 
Mattelart \& Neveu, 2004).From this perspective, Clarisse, January et al (2006) and Mc Hale et al. (2001) note that the lower- youth class watch more TV, read less, have more outdoor games unstructured at the expense of indoor activities mobilizing imagination and construction. It appears that the structured practices and "demanding" strengthen the academic and social adjustment (Marsh, 1992). Instead, those less structured (street sports) are relatively tragic youth (Eccles\& Barber, 1999. Mahoney et al, 2003).It should also be pointed out that attendance increases with socioeconomic status (cultural and economic capital). Moreover, the economic reasons not topped the list of impediments to exit the show, the lack of time is often cited with $42 \%$ and $27 \%$ of respondents mentioned the lack of interest (Eurobarometer, 2007). Another study (Cassard, 2008) is to confirm these results but at lower proportions. The most important barriers are related to the allocation of two scarce resources: money $(26.99 \%)$ and the time $(22.21 \%)$. Other factors were also discussed such as the accessibility of sites. Indeed, the students surveyed prefer to go to events that are close to home or if well served by public transport.

Similarly, over time, the life rhythm and the cultural practices of young people change. Bourget, Chenu, \& al (1997) distinguish two types of students: the first is a studious student, reflects the traditional image of the heir (Bourdieu \&Passeron, 1964) and preparatory class. He watches a lot television. His field of leisure is relatively small and mainly focused towards the outside of the house. It goes to the cinema occasionally in the evening or finally at the restaurant, he reads a lot. As against the second is qualified student athlete sleeps a lot and has a school delay. His hobbies are focused on the sport, but also a group of friends.

\section{Method and Materials}

After a semi structured interview conducted with 12 young people from the region of Sfax. We have reached a final questionnaire composed of 24 questions. Our investigation focused on 350 young students aged 15 to 25 years, high school students and students from both sexes studying in a college or university in Sfax. Through the kindness of the teachers, we have recovered more than half of the questionnaires (219 of 350, or $62.57 \%$ ). To identify the cultural practices of young people in school, we used frequency tables of answers to questions. The percentages have little value because they depend on the nature of the questionnaire (open or closed questions, multiple choice questions...), but the general structure analysis of responses allowed us to generate valuable insights into the cultural practices of young people. We used the chi-square to identify the relationship between the dependent and independent variables.

\section{1- Leisure Time and hobbies}

\section{Results and discussion}

Nearly 4 out of 10 young students say "enough time to do what they want" in their leisure time (Fig. 1). The perceived lack of time is related to the different situations: it is present in schools and universities where studies are strong constraints (time use often loaded tests, reviews etc.) (Bourget, Chenu et al. 1997).

Lack of money for this social category to enjoy growing supply of goods and services in the leisure market also expresses the socio-economic frustration that affects the choice of leisure and Sfaxian youth leisure (Bourdieu \& Passeron, 1964; Cassard, 2008). 36.1\% said they sometimes or often nothing specific to do. Almost half (48.4\%) of school girls have a sense of lack of time or often have nothing specific to do (Fig. 1). This high percentage is explained by the social and economic environment in which they live. Thus, these girls have little suction and shortly (studies, housework ...) and therefore less able to enjoy leisure opportunities than boys (David, 2011, October, 2009; Donnat, 2006).

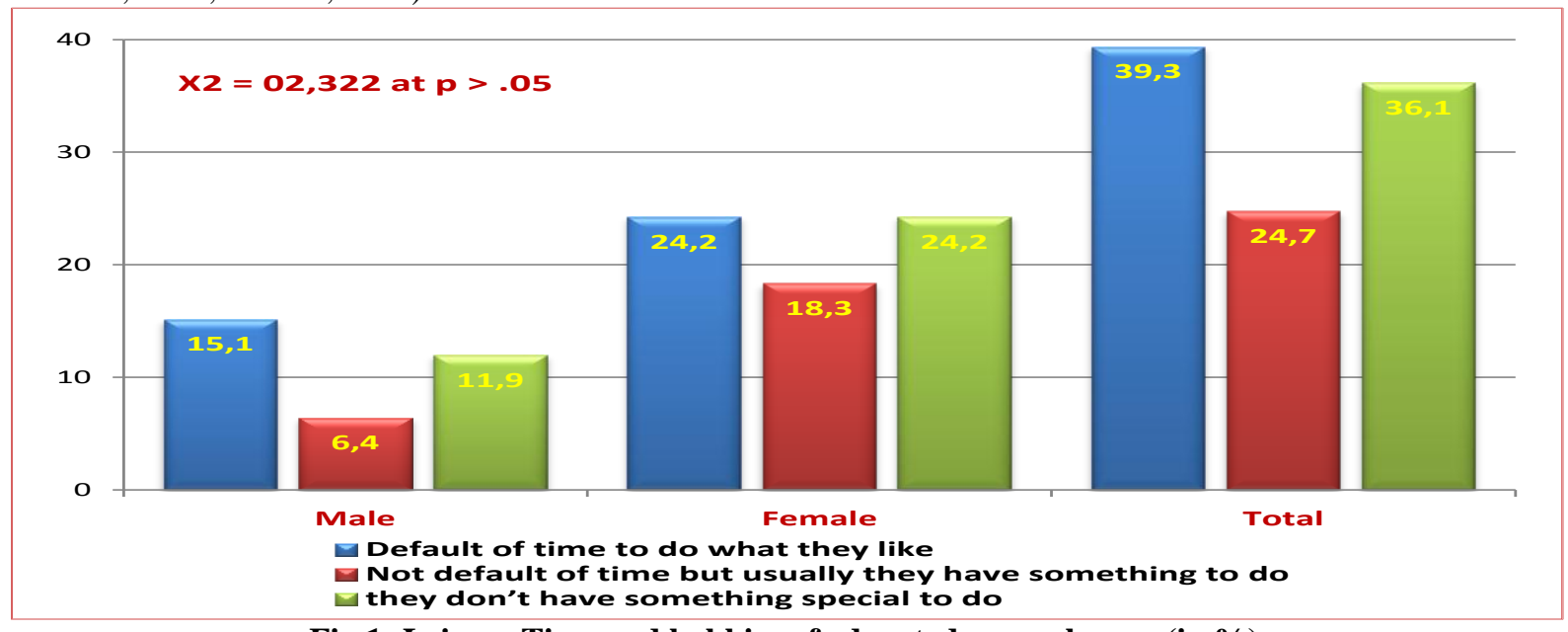

Fig 1: Leisure Time and hobbies of educated young by sex (in \%) 
The relationship between free time and the educational attainment of young Sfaxians, permit us to accept the alternative hypothesis of dependence between these two variables at $5 \%$ as a maximum risk of making a bad decision (Fig. 2).

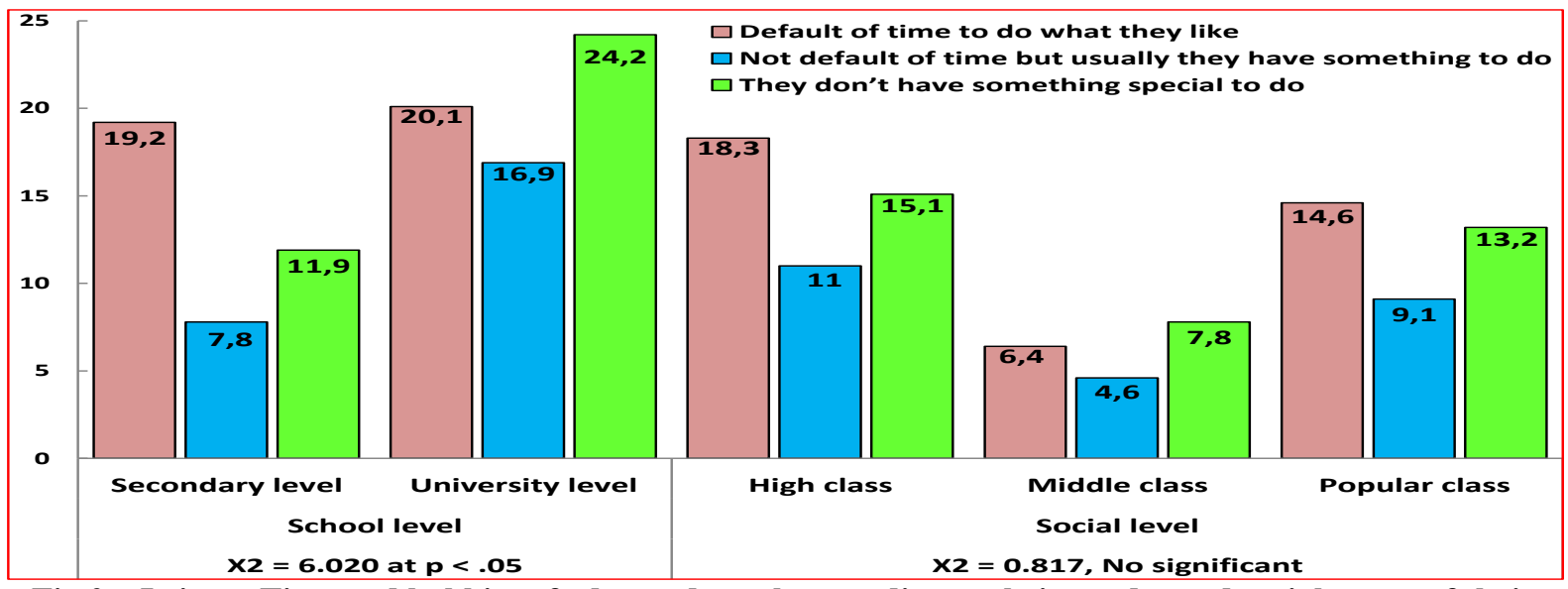

Fig.2 - Leisure Time and hobbies of educated youth according to their grades and social status of their parents (in \%).

Almost half (44.3\%) of young scholars say lack of time and sometimes or often nothing specific to do against $31.1 \%$ in secondary schools (Fig. 2). The perceived lack of time in turn increases with parent's socioeconomic level of young people. Nearly $33.4 \%$ of school youth have a sense of lack of time or often have nothing specific to belong to the upper class (Fig. 2).

\section{2-Sociability and Night's youth outputs}

Being young and single promotes leisure fashion outward. Indeed, the educated youth of the region of Sfax admit their preferences for leisure activities that help them to leave their homes (65.3\%) (Donnat, 1998). This growing desire for external activities is among girls with $40.6 \%$ (Fig. 3).

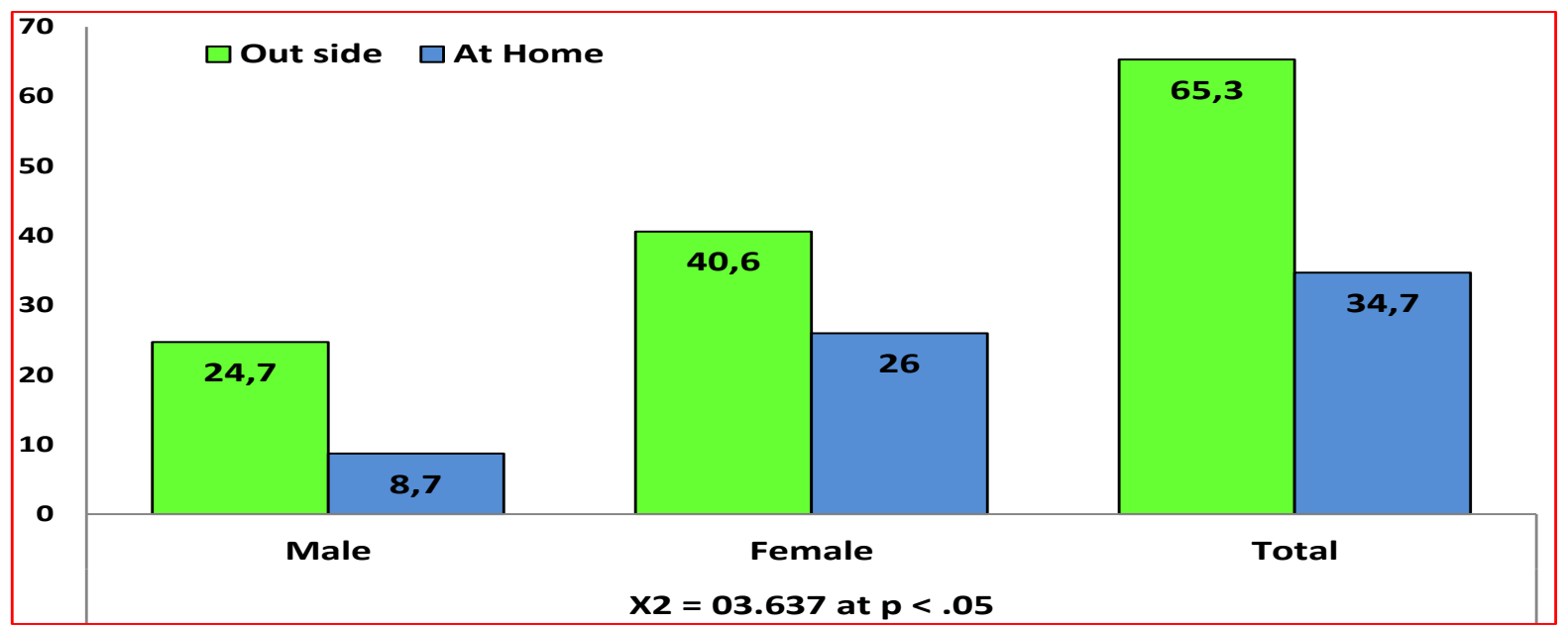

Fig.3-Leisure activities practice by gender (in \%).

The externality in the cultural practices of young girls is a recent phenomenon in our Tunisian society, access to the world of men is regulated by social status (traditional order, religious and legal and policy Order etc...).Thus, through these cultural practices, young school girls express their aspirations and assert their freedom by the new ownership of shares reserved spaces before to men. They leave the conditions of their lives and traditional norms (faithful ideal procreative wife, respectful and responsible etc.) And adopt a new status as a full-fledged citizen, free to choose and to undertake. The School youth reject leisure practices with a sociability centered on the family. They tend to develop a strong friendly sociability (Bauger 2000; Hersent, 2004). In fact, $70.3 \%$ of young people prefer activities that are with friends, $47 \%$ are girls (Fig. 4). The family life according to Dumazedier (1988) has become more open to outside influences (Outer directed) (Riesman, Denney \& Glazer, 1955) and aspirations of individuals to a personal life in relation to peer group (peer groups). 
When the young educated away from home territory marks a way to say, to build his world and forge an identity (Zaffran, 2010; Hamonic, 2003). Being far outside the family, young conquered new spaces (spaces of visibility, sociability, friendships) in response to institutional and social maladjustment in developing sociability street to get them to "make as others"The "outside" is not only in the eyes of Sfaxians youth means to distance himself from the family and school institutions, symbols and spaces artificial time, but time is a free choice of activity and free geographic destination. "Where you want, when you want, with who wants" in the words of a young person.

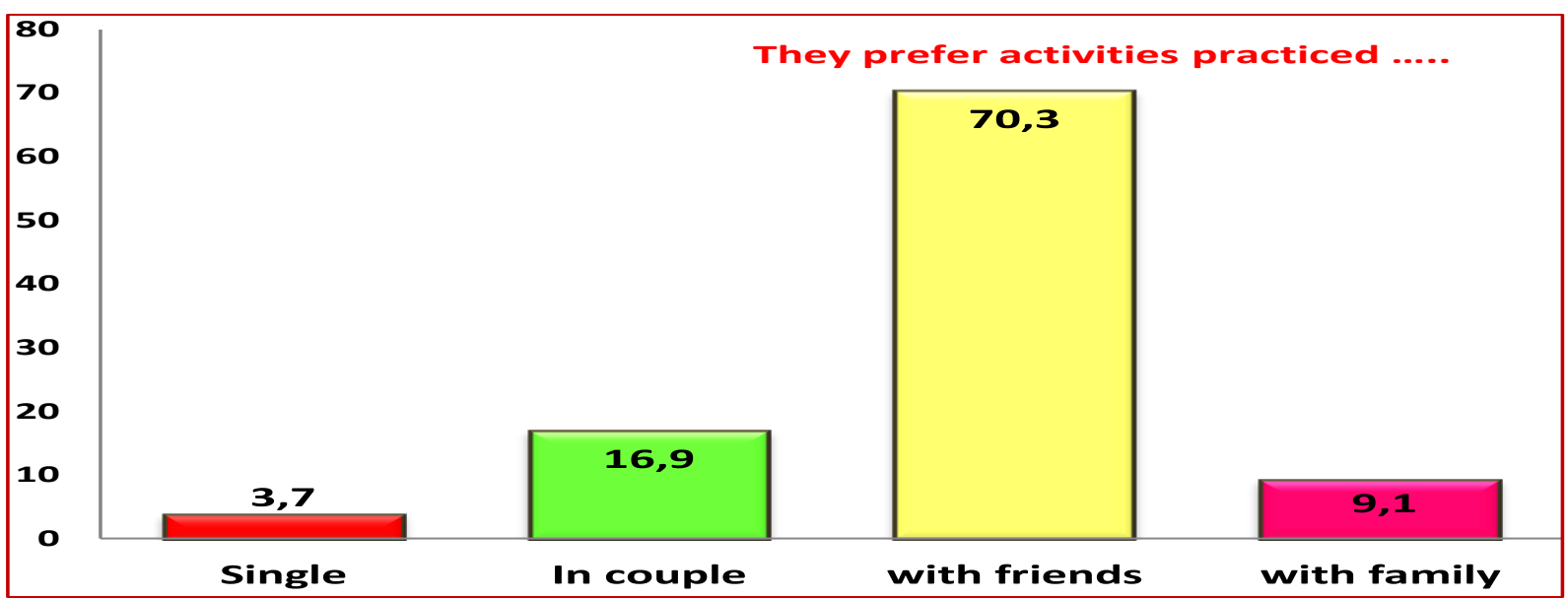

Fig.4 - Sociability of cultural practices among young people (in \%)

Frequently night outputs are a typical behavior of young people, especially when they are single. More than four in ten out at night at least once a week, and only $18.3 \%$ never do. Girls fare worse than boys ( $16.9 \%$ of girls are almost never out at night against 1.4\% of boys).Despite some changes in the lifestyle of the Sfaxians family, it is still attached to the traditional model of women. Girls in Arab-Muslim society raise more confusion and attention from parents regarding their activities, outputs and their friendships than boys. Indeed, girls are listed in the appearance of the familiar surroundings, as the contrast between the public sphere, masculine, and female private worlds (Bourdieu (1998: 65).

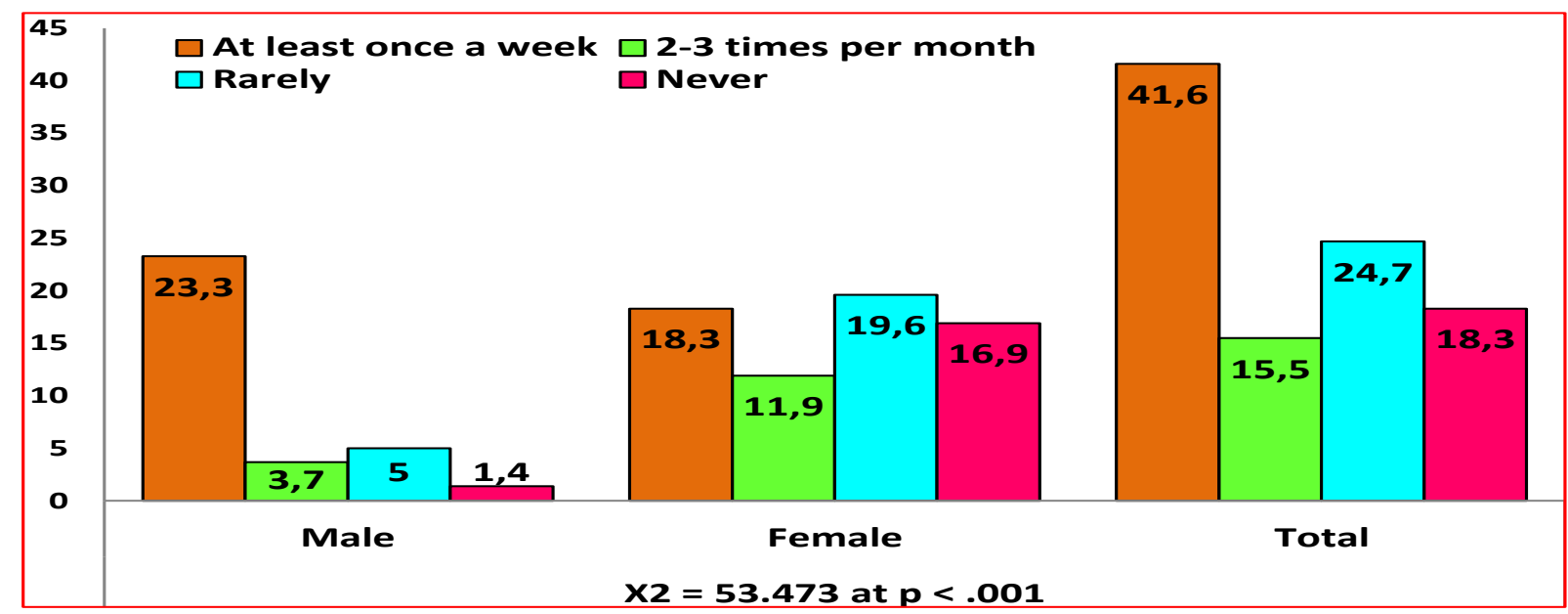

Fig.5 - school's youth Nightlife and sex (in \%).

This difference in practice between the two sexes in a fit young parentage and kinship network to interact differently with their outside world. The primary role of the sfaxians family is to help children understanding that to be loved and appreciated, you must register "in the order of things" (Bourdieu 1998: 63). That is to say internalize both cultural habitus of class habitus and gendered habitus (Bourdieu, 1979).

The most common youth nightlife is to visit parents (uncles, aunts, grandparents etc...). $25.1 \%$ of young people are gone during the last twelve months (Fig. 6). This high percentage shows the deep commitment of young Sfaxians to the family. $16.6 \%$ went with friends, $14.5 \%$ of young people leave the restaurant or to see a show and finally, $12.5 \%$ went to the cafe. 


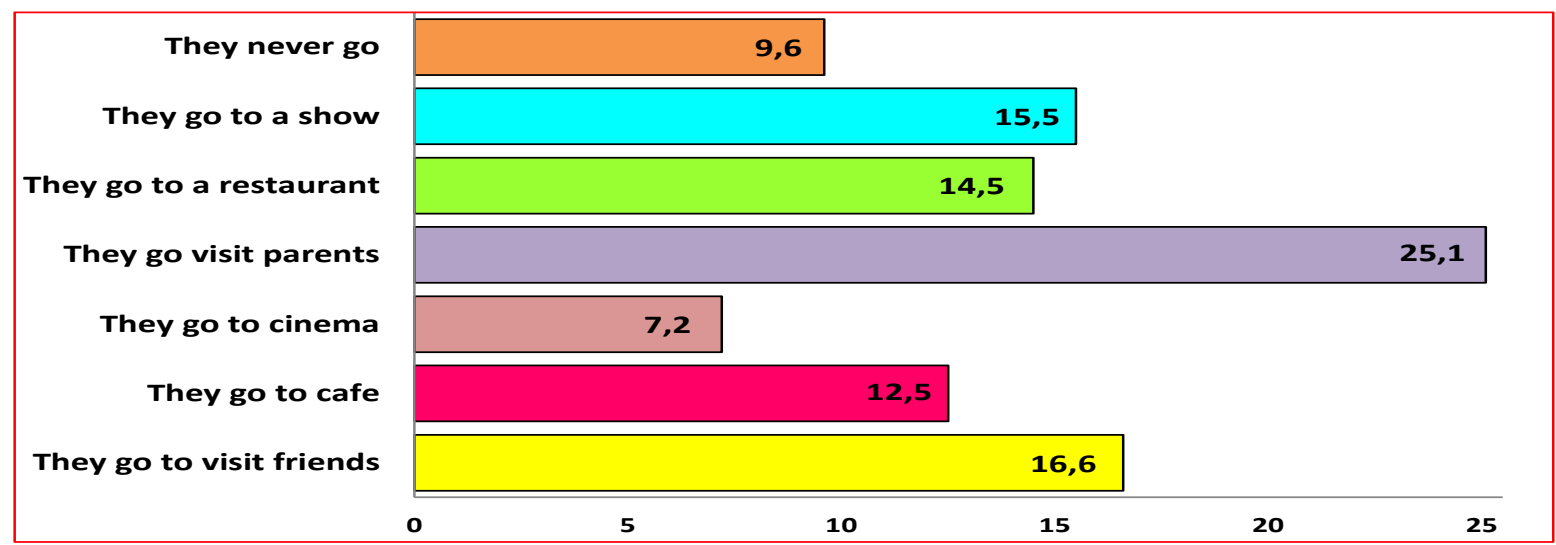

Fig. 6 - school youth Nightlife (in \%).

\section{3) The cultural practices of youth}

About $80.36 \%$ of youth believe that where they live is poorly located in terms of cultural facilities (Fig. 7). The relative dissatisfaction expressed through these percentages is rooted in actual removal equipment. The majority of equipment cinemas, library, cultural centers, and theaters are located downtown. It takes at least 3/4 hours to reach these equipments. Thus, and according to the work of Cassard (2008), the educated youth prefer to go to cultural events that are near their home or property if served by public transit.

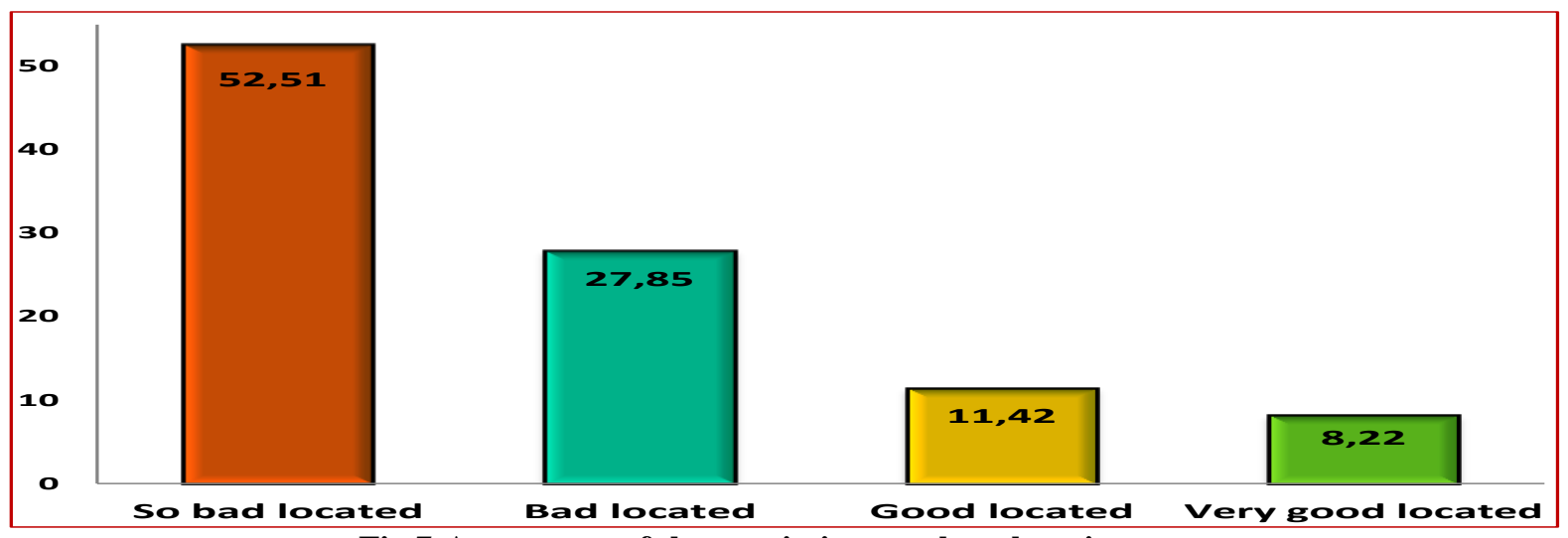

Fig.7-Assessment of the proximity to cultural equipments.

Over the past twelve months, students attend from time to time cultural equipments. The majority of them, just under three-quarters $(65.30 \%)$ would like to go more frequently. The three main reasons that hinder the attendance of young to cultural equipments are the economic causes (lack of money, the price of tickets and travel costs), lack of time and finally the removal of equipment. This is in line with the work of Cassard (2008), and Bourget, Chenu \& Vilter (1997).

When we look at the cultural practices of sports through video games and crossword, cultural practices appear close to sports practices and other outdoor activities such as hiking and running walk. In primitive society, hiking, gardening, cooking and makes physical activities were utilitarian practices. To survive, humans (Homo Faber) (Frisch, 1957) engaged in gathering activities, fishing and hunting. These activities are the traditional type of other reasons, less utilitarian and economical, psycho cultural. Fishing, hunting and safari become an expression of fun to be measured with a wildlife tends to disappear from civilization.

Faced with this "do it yourself" of the modern era, more than half of young people practice or have practiced walking and $45.2 \%$ say they practice or have practiced a sport, followed by the preparation of good food and good cakes and card games (fig. 8).

Overall aspirations seem somewhat related to gender, although girls tend to perform activities that are known feminist such as sewing, making good food etc.. $30.7 \%$ of girls would benefit from the opportunity to focus on their domestic and family activities to prepare good food and good cakes. The act of creation and art of cooking, in the Sfaxian young girls is more than a simple extension that Wallon (1942) calls for kids "games manufacture" a late work by a living recreation. 


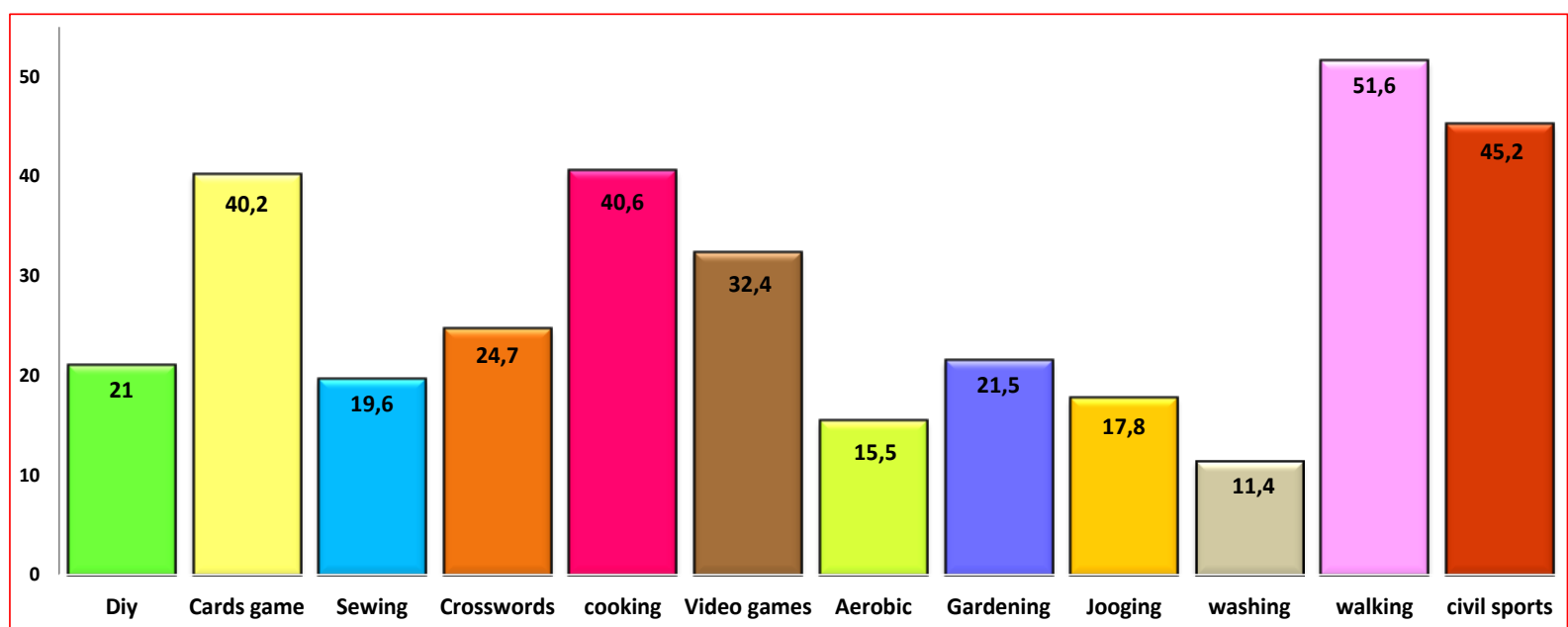

Fig. 8 - Cultural practices of young people (in \%).

\section{4) Reading habits}

Reading is another practice that reveals a little more cultural universe of young people and their specific tastes. An overwhelming majority of educated youth of both sexes are interested in the daily press ( $90.79 \%$ of school youth read a daily newspaper almost every day).The young people give priority to reading the newspaper "Ads" with 32.9\% just behind the "Chourouk" with 21.1\% (Fig. 9). In this age group, the main reason seems to be the relaxation or relaxation out of the routine studies. Indeed, we read to learn especially sporting events and world artists, learn and make them aware of social problems.

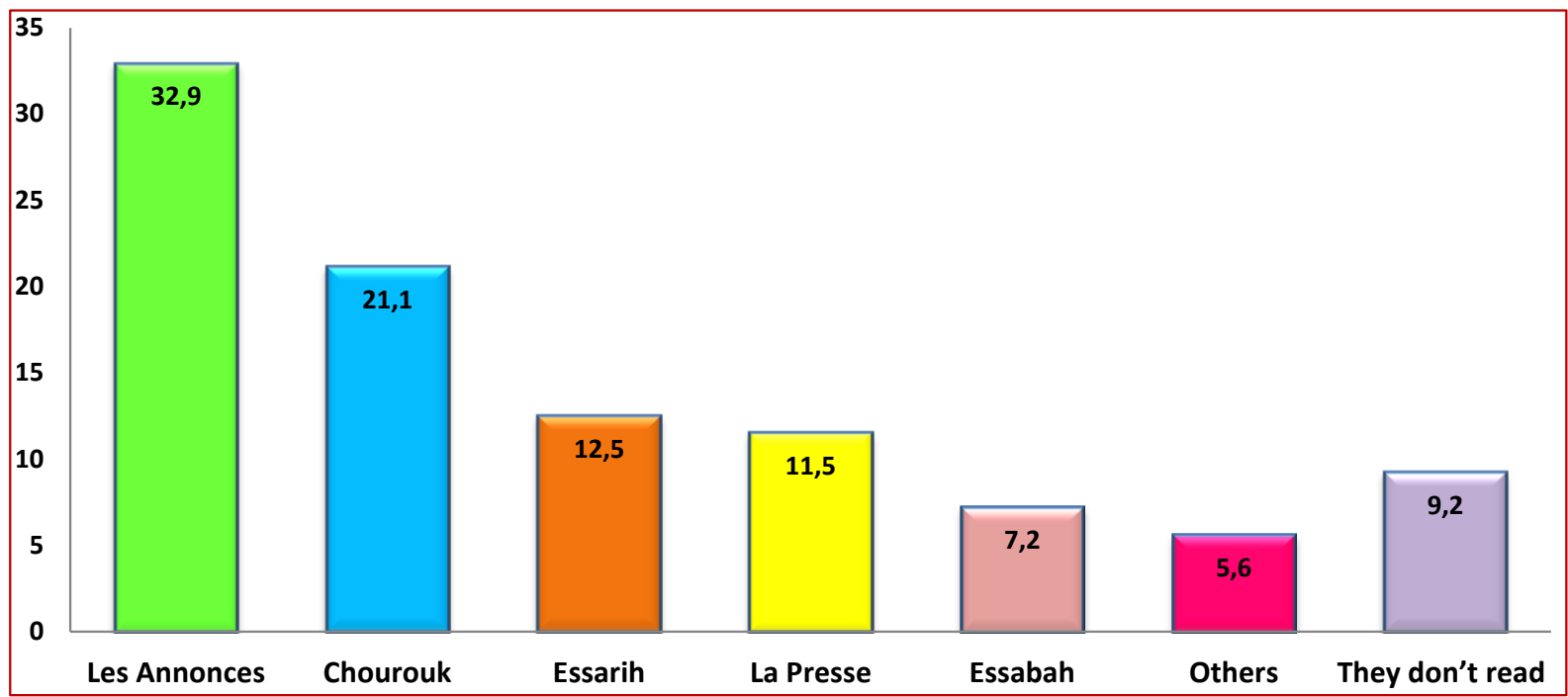

Fig. 9 - Reading habits (books and journals) of young people (in \%).

It is very rare is exceptional live today in a home where the book is totally absent. The girls show more pronounced than their male counterparts in reading (69\% of women read a book in the last twelve months, against only taste $31 \%$ for boys) (October, 2011).This difference is more accentuated between the sexes when it comes to the type of the book. Sfaxian young girls have a preference for literary books and especially novels, or $26.9 \%$ of readings. In addition, girls are also more abundant to treat books of decorations and art books that affect them personally, such as home, health and even the esoteric (14.3\% prefer books and decorations 'arts against $1.8 \%$ for boys).We should note that the number of investigations still join positively the fact of being a woman at the discretion of the "legitimate" Culture (Bihagen et al, 2000; Gerro-Katz, 2000; Callier et al, 2012).Moreover, young people are also interested in reading comics books and books on computers and personal computers (Tab.1). 
Tab.1 - Types of books read by sex and educational level of young people (in \%).

\begin{tabular}{|l|c|c|c|c|c|}
\cline { 2 - 6 } \multicolumn{1}{c|}{} & \multicolumn{3}{c|}{ Gender } & \multicolumn{2}{c|}{ School level } \\
\cline { 2 - 6 } \multicolumn{1}{c|}{} & Male & Female & Total & Secondary level & University level \\
\hline Arts & 1,1 & 5,7 & 6,8 & 4,2 & 2,6 \\
\hline Comic Strips & 2,4 & 8,6 & 11 & 7,1 & 4 \\
\hline Decoration & 0,7 & 9,9 & 10,6 & 4,2 & 6,4 \\
\hline Historic & 3,1 & 2,4 & 5,5 & 2,2 & 3,3 \\
\hline Data Processing & 5,3 & 6 & 11,3 & 4 & 7,3 \\
\hline Literature & 2,4 & 8,4 & 10,8 & 4,6 & 6,2 \\
\hline Politics & 4 & 2,2 & 6,2 & 1,8 & 4,4 \\
\hline Romance & 5,7 & 21,2 & 26,9 & 11,9 & 15 \\
\hline Scientific & 5,5 & 4,2 & 9,7 & 4,2 & 5,5 \\
\hline Other Books & 0,8 & 0,4 & 1,2 & 0 & 1,1 \\
\hline
\end{tabular}

\section{5) Preferences for broadcasting.}

The behavior of young people towards the radio and television to suggest that our young people listen and watch a lot of these two types of media. The majority of young people in school say they have listened to the radio $(80.6 \%)$ or watching television $(98.6 \%)$ at least once per day (Fig. 10).

The time reserve boys and girls listening to the radio and television is different. Rather, the distinction comes from the choice of being listened to or watched programs that clearly show the characteristics of youth preferences. Almost half of young people (46.5\%) prefer the musical dimension (varieties) to the radio with different proportions between the two sexes (32.6\% for girls against $14 \%$ for boys). This behavior fits perfectly with their lifestyle. This strong musical hearing is due to the fact that the Tunisian girl spends her free time at home. So she listens to the radio doing his chores.

Indeed, music is ubiquitous in the lives of young people. All, or almost, in listen regularly. The "youth" culture is expressed prominently by listening to oriental music rhythm and atmosphere. $37.4 \%$ of young people prefer to listen to this kind of music (Fig. 10). It is through music that young people can express themselves and find their identity. As well as Armanda and Arseneault (1998), "young people define music in their own values, which leads to categorize it in deferent musical styles. A musical style codes comprises a set of its own, in addition to being characterized by specific values ".

After the radio and television, disc and player are still the most used by young people to listen to music. Youth choose Internet as an alternative source more or less common among them. Finally, the player allows many of these young people to carry their music with them and listen to where they see fit.

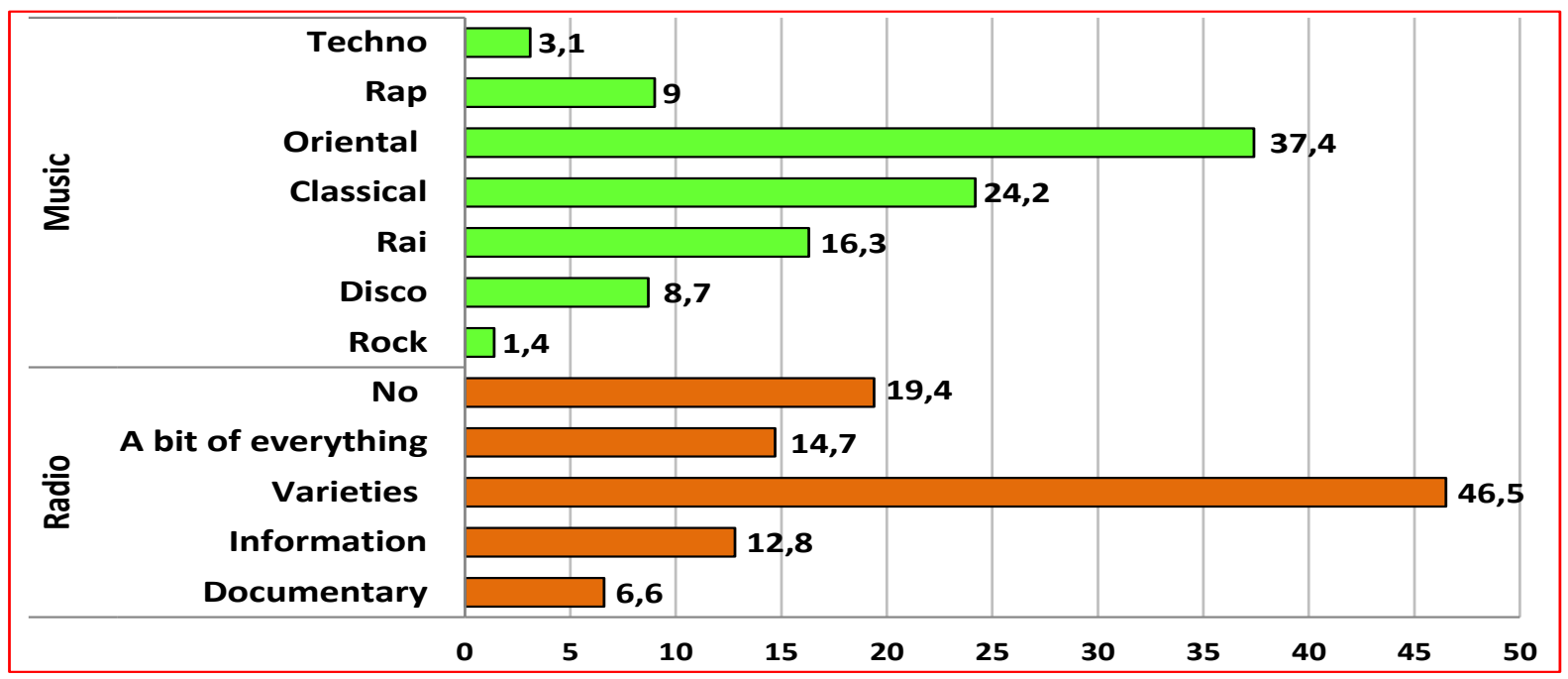

Fig.10 - types of music and listened programs at the radio (in \%)

Regarding to the television programs most watched by our educated youth, we reveal some interesting differences between the two sexes of the respondents. Indeed, Figure 11, we highlights own cultural universe sometimes boys, sometimes girls. The documentary programs are less popular among one and the other sex. The young men are more likely than girls to watch sports on television (15.1\% vs. 4.6\%).However, listening varieties and series is clearly predominated by girls with much higher proportions. $16 \%$ of girls look varieties and $14.6 \%$ following series against respectively $2.7 \%$ and $2.3 \%$ for boys, Monnot (2009). 


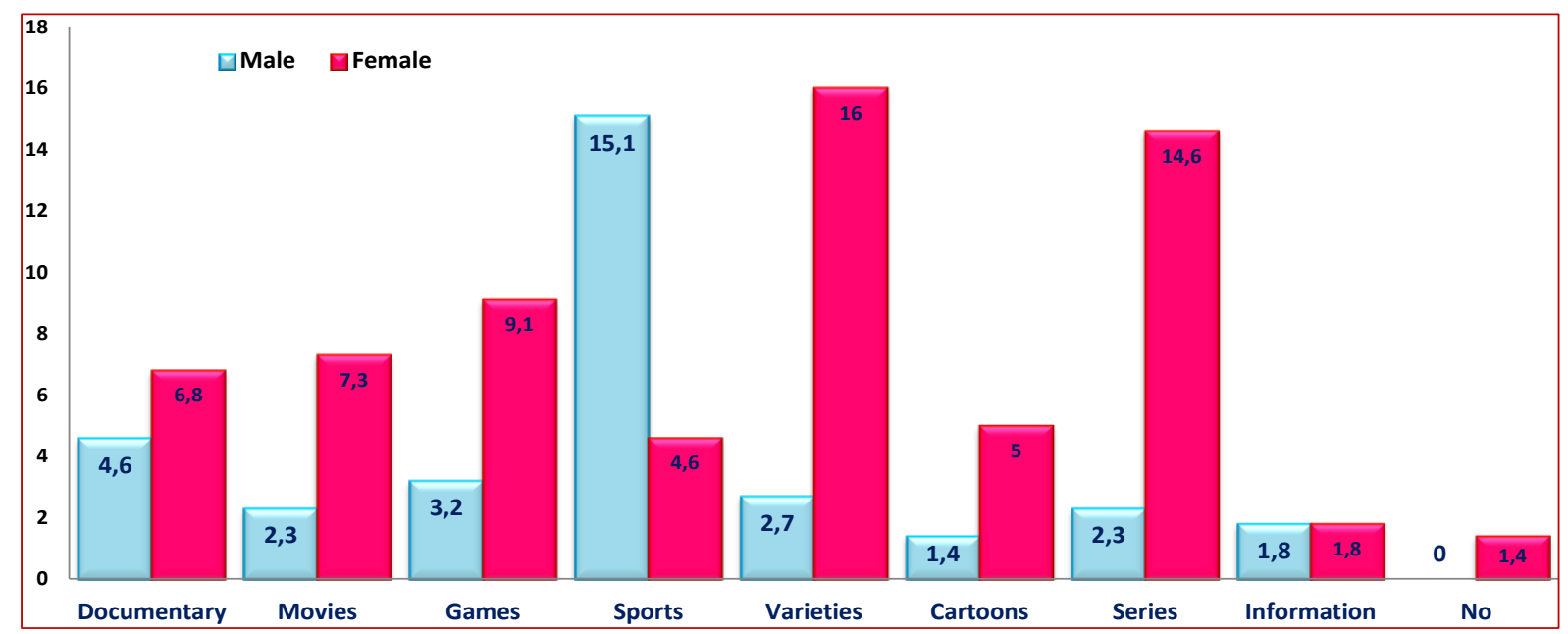

Fig.11-Types of programs watched on television by sex (in \%)

\section{6) The practice of sport and physical activity}

A number of young people enrolled in the Sfax region seeking to improve in the field of sport and physical activity following workouts. Almost half of young people surveyed engage in civil sports that can physically possess a license. The individual sports are slightly more common than the other ones (fig. 12).Young athletes are less engaged in the activities of opposition (Opposition: presence of opponents, lack of partners and uncertainty, such as judo and karate etc.). And uncertainties activities (Mouvent environement: the presence of uncertainty and lack of opponents and partners, such as sailing solo climbing and scuba diving, Ski etc.).

The interests of motor praxiology also vary by gender. Young boys especially practice sociomotor activities (basketball, football etc...), That is to say, competitive and relational domination of socio-emotionnels type (Parlebas 1986). By cons girls engage more with psychomotor activities (stable environement) as the gymnastics, the dance, the swimming, the athletics etc. They seek affiliation and freedom. They respectively

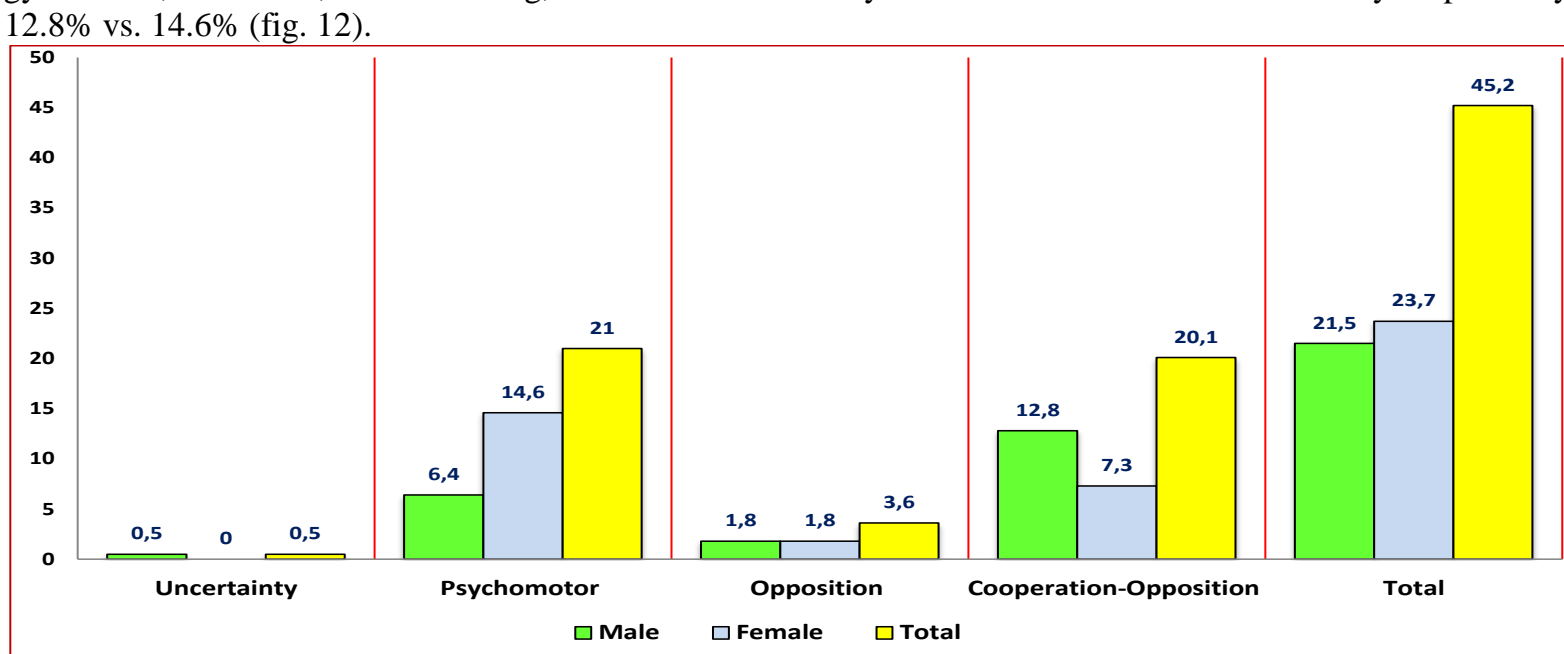

Fig.12-ludo driving practices of young people in a civilian club according to sex (in \%)

\section{Conclusion}

Cultural practices should be defined in a general framework of a social project that encompasses all forms of collective Tunisian youth. In a society where the reduction of working time continues and where the circumstances of work and / or family (unemployment, divorce ...) force more people to adapt and reflect their social identity. These cultural practices have become the real cultural issues. They are often identified high aspirations for self-expression and research and compliance, as, carriers of identity, personal or collective.

All these changes were most often seen as specific phenomena to the "youth culture".

- Nearly four out of 10 young people at school say "enough time to do what they want" in their spare time.

- Nearly half (48.4\%) girls have a sense of lack of time or often have nothing specific to do during their free time. 
- Being young and single promotes leisure fashion turned outward. $65.3 \%$ of young people prefer leisure activities that cause them to leave their homes which $40.6 \%$ are girls.

- These young people reject the leisure practices with sociability centered on the family. They tend to develop a strong friendly sociability. $70.3 \%$ prefer activities that are with friends.

- Prefer to read novels (26.9\%), hear oriental music (37.4\%).

- Over three quarters of young people listen to radio and watch TV. They prefer to read the daily newspaper ads (32.9\%), watching sports programs on TV (19.6\%) and finally, listen to the radio varieties.

- Finally, almost half of young people engage in civil sports and especially individual sports. The sociomotor games are male dominant and psychomotor games are dominant female.

\section{Bibliography}

[1]. Amri, L. (2007). Les changements sociaux en Tunisie, Paris, l'Harmattan.

[2]. Armanda, D., Arseneault, Y., (1998). Pourquoi les jeunes Québécois francophones préfèrent-ils la musique anglophone? Rapport présenté au ministère de la Culture et des Communications du Québec, Québec.

[3]. Bauger, P. (2000). Les pratiques de loisir, de rencontre et d'information des jeunes haut-rhinois, rapport de synthèse, La Direction Départementale de la Jeunesse et des Sports du Haut-Rhin, Juin 2000, [In ligne], http://koebel.pagesperso

orange.fr/pdf/Pratiques.pdf.

[4]. Beaud, S. (1997). Un temps élastique. Etudiants des « cités » et examens universitaires, Terrain, n²9, p.50

[5]. Beck, U. \& Edgar, G. (2010). Les variétés de seconde modernité: expériences et perspectives extra-européens et européen, British Journal of Sociology, vol 61, Issue 3, Pages 406-638.

[6]. Bihagen, E., Katz-Gerro, T. (2000). Culture consumption in Sweden: the stability of gender differences, Poetics, 27 (5-6), p.327349

[7]. Bourdieu, P. \& Passeron, J.C. (1964). Les héritiers : les étudiants et la culture, Paris, Les Éditions de Minuit.

[8]. Bourdieu, P. (1979). La Distinction, critique sociale de jugement, Editions Minuit, Paris.

[9]. Bourdieu, P. (1998). La domination masculine, Editions Seuil, Paris.

[10]. Bourget, J., Chenu, A., Samuel, O. \& Vilter, S. (1997). Les pratiques culturelles des étudiants de 1'UVSQ, enquête 1995/1996, Observatoire de la vie étudiante, Université de Versailles.

[11]. Callier, L. Harquinet, L., Guerin, M., \& Genard, J.L. (2012). Etude approfondie des pratiques culturelles de la population en fédération Wallonie-Bruxelles, Etudes n ${ }^{\circ}$, novembre 2012, p.1-64.

[12]. Campeau, R, Sirois, M. \& al. (1993). Individu et société : Introduction à la sociologie, Editions Gaëtan Morin, Québec, 1993, p.121.

[13]. Cassard, S. \& al. (2008). Etude sur la fréquentation et les pratiques culturelles des étudiants de l'Université d'Auvergne, Faculté des Sciences Economique et de Gestion. [In ligne] www.letransfo.fr/content/download/.../Etude\%20 culture\%20UdA-2.pdf

[14]. Cassard, S., Comptour, G., Cuinet, V. \& al. (2008). Etude sur la fréquentation et les pratiques culturelles des étudiants de l'université d'Auvergne, Master 1 Analyse des Politiques Economiques, Faculté des Sciences Economiques \& de Gestion [In ligne] www.letransfo.fr/content/download/.../Etude\% 20culture\%20UdA-2.pdf.

[15]. Chéreau, M. \& Lanlay, A. (2004). Les marchés culturels et les jeunes, DEPS (Travaux du DEPS), Paris.

[16]. Clarisse, R., Janvier, B. \&Testu, F. (2006). Aménagement du temps de l'enfant: temps scolaire et périscolaire, rythme de vie et performances. In O. Megalakaki, A. Lancry \& U. Kittler (éd), aménager les temps de vie des enfants ? Rhythmisie rung von Kindheit: einBlicknachFrankreich (pp.62-69).

[17]. David, O., (2011). Le temps libre des enfants et des jeunes à l'épreuve des contextes territoriaux, Travaux et Documents de l'UMR $6590, \mathrm{n}^{\circ} 31$, mai 2011, pp. 25-32.

[18]. De Singly, F. (2006). Les Adonaissants. Paris, Armand Colin.

[19]. De The, G. \& Hubert, A. (1988). Modes de vie et cancers, Paris, Robert Laffont, 1988.

[20]. Derbaix, C. \& Leheut, E. (2008). Adolescents : implication envers les produits et attitude envers les marques, Recherche et Applications en Marketing, 23, 2, pp.37-66

[21]. Detrez, C. (2002). La construction sociale du corps, Le Seuil, Paris.

[22]. Détrez, Ch., Mercklé, P., Veyret, M. \&Vuattoux, D. (2005). C'est votre défilé... : le défilé de la biennale de Lyon, entre discours et réalités, in Hossard Nicolas, Jarvin Magdalena (dir.), «C'est ma ville !» De l'appropriation et du détournement de l'espace public, Paris, L'Harmattan.

[23]. Donnat, O. (1998). Les pratiques culturelles des français: enquête 1997 (enquête conçue et réalisé par le) Département des études et de la prospective, Ministère de la Culture et de la Communication.

[24]. Donnat, O. (2005). La féminisation des pratiques culturelles, développement culturel, $\mathrm{n}^{\circ} 147$.

[25]. Donnat, O. (2009). Les pratiques culturelles des Français à l'ère numérique: enquête 2008, Paris, la Découverte/ Ministère de la culture et de la communication

[26]. During, B., (1984). Des jeux aux sports: repères et documents en histoire des activités physiques, Editions Vigot, Paris.

[27]. Eccles, J. S. \& Barber, B. L. (1999). Student council, volunteering, basketball, or matching band: what kind of extracurricular involvement matters? Journal of adolescent research, 14, 10-43.

[28]. Eurobaromètre Spécial. (2007). Les valeurs culturelles européennes, sondage commandité par la commission européenne, $\mathrm{n}^{\circ} 278$.

[29]. Faure, S. \& Garcia, M-C. (2005). Culture hip-hop, jeunes des cités et politiques publiques, Paris, La Dispute.

[30]. François, S. (2007). Les fans fictions, nouveau lieu d'expression de soi pour la jeunesse?, Agora, n 46, pp.58-69.

[31]. Frisch, M. (1957).Homo faber, The first English edition, translated by Michael Bullock, was published in 1959, in London, England by Abelard-Schuman.

[32]. Gagnon, G. \& al. (1997). La culture en pantoufles et souliers vernis: rapport d'enquête sur les pratiques culturelles au Québec, Sainte-Foy: Les Publications du Québec.

[33]. Garton, A.F. \& Pratt, C. (1991). Leisure activities of adolescent school students: predictor of participation and interest. Journal of adolescence, 14, 305-321.

[34]. Gauthier, M. \&Mercier, L. (1994). La pauvreté chez les jeunes. Précarité économique et fragilité sociale. Un bilan, Québec: IQRC.

[35]. Gauthier, M., Molgat. M. \&Saint-Laurent, L. (1999). Lien social et pauvreté: repérage et profil des jeunes précaires qui vivent seuls en milieu urbain, (rapport de recherche). Sainte-Foy: INRS Urbanisation, Culture et Société

[36]. Gidden, A. (2007). The Constitution of Society: Outline of the Theory of Structuration, Polity Press, Cambridge, UK

[37]. Goffman, E. (1987). Façons de parler, Editions de Minuit, Paris. 
[38]. Hamonic, V. (2003). Culture et adolescence: référents et conflits dans la quête d'identité, mémoire, Institut de formation des Maîtres de l'Académie de Lyon.

[39]. Hersent, J.F. (2004). Le(s) public(s) de la culture, BBF, n 3, p. 133-134 [en ligne] <http://bbf.enssib.fr/> Consulté le 19 novembre 2013.

[40]. Hersent, J-F. (2003). Les pratiques culturelles adolescentes, BBF, 2003, nº 3 , p.12-21

[41]. Horellou-Lafarge, Ch. \& Segre, M. (2003). Sociologie de la lecture: L'institution scolaire et le goût de lire, Editions La Découverte

[42]. Katz-Gerro, T. \& Oriel Sullivan, O. (2004). Loisirs, Goûts et Appartenance Sexuelle en Grand-Bretagne: Évolution entre les Années 1960 et 1990, Sociologie et Sociétés XXXVI, 1:165-186. [Leisure, Tastes and Gender in Britain: Changes from the 1960s to the 1990 s].

[43]. Katz-Gerro, T. (1999). Culture consumption and social stratification: Leisure activities, Musical tastes and social location, Sociological Perspectives, 42 (4), p.627-646.

[44]. Kaufman, J. \&Gabler, J. (2004). Cultural capital and extracurricular activities of girls and boys in the college attainment process, Poetics, 32, 2, pp. 145-168

[45]. Kindelberger, C., Le Floc'h, N. \& Clarisse, R. (2007). Les activités de loisirs des enfants et des adolescents comme milieu de développement, revue L'orientation scolaire et professionnelle, 36,4, p.1-15, http:/osp.revues.org/1527.

[46]. Kracman, K. (1996). The effect of school-based arts instruction on attendance at museums and the performing arts, Poetics, 24 (24), p.203-218.

[47]. Lartet-Geffard, J. (2005). Le Roman pour ados. Éditions du Sorbier.

[48]. Lipani-Vaissade, M.Ch. (2005). Impact des quotidiens gratuits Metro et 20 minutes sur la lecture de la presse quotidienne par les 17-25 ans vers la constitution d'un public distinct et typique ? Thèse de doctorat en Sciences de l'information et de la communication (dir. Michael Palmer), Université Paris III - Sorbonne Nouvelle, 14 novembre 2005.

[49]. Mahoney, J. L., Cairns, B. D. \& Farmer, T. W. (2003).Promoting interpersonal competence and educational success through extracurricular activity participation.Journal of educational psychology, 95, 409-418.

[50]. Malinowski, B. (1944), Une théorie scientifique de la culture et autres essais, Maspero, Paris, 1968.

[51]. Maresca, B. (2004). L'intensité de la consommation culturelle, signe d'urbanité, in Les mutations technologiques, institutionnelles et sociales dans l'économie de la culture, sous la direction de René Teboul, Paris, l'Harmattan.

[52]. Marsh, H. W. (1992). Extracurricular activities: beneficial extension of the traditional curriculum or subversion of academic goals? Journal of educationalpsychology, 84, 553-562.

[53]. Mattelart, A. \& Neveu, E. (2004). Introduction aux Cultural Studies, La découverte, Coll. Repères.

[54]. Mc Gee, R., Williams, S., Howden-Chapman, P., Martin, J. \& Kawachi, I. (2006). Participation in clubs and groups from childhood to adolescence and its effects on attachment and self-esteem. Journal of adolescence, 29, 11-17.

[55]. Mc Hale, S.M., Crouter, A.C. \& Tucker, C.J. (2001). Free-time activities in middle childhood: links with adjustement in early adolescence, Child development, 72, p.1764-1778.

[56]. Metton, C. (2007). Sociabilité des collégiens et nouveaux moyens de communication. Thèse de sociologie, EHESS.

[57]. Monnot, C. (2009). Petites filles d'aujourd'hui. L'apprentissage de la féminité, Paris, Éditions Autrement (coll. Mutations).

[58]. Octobre, S. (2004). Les loisirs culturels des 6-14 ans, Editions la documentation française.

[59]. Octobre, S. (2009). Pratiques culturelles chez les jeunes et institutions de transmission: un choc de cultures ?, Culture prospective, $\mathrm{n}^{\circ} 1, \mathrm{p} .1-8$

[60]. Octobre, S. (2011). Du féminin et du masculin: Genre et trajectoires culturelles, Réseaux, 4-5, n 168-169, p.23-57, Paris, La Découverte.

[61]. Oetting, E-R. \& Beauvais, F. (1991). Orthogonal théorie de l'identification culturelle: l'identification culturelle des adolescents en situation minoritaire, vol. 25, $\mathrm{n}^{\circ} \mathrm{S} 5$-S6, Pages 655-685

[62]. Parlebas, P. (1986). Eléments de sociologie du sport, Paris, Presses Universitaires de France.

[63]. Parlebas, P. (1999), Jeux, sports et sociétés. Lexique de praxéologie motrice, Paris, Édition INSEP.

[64]. Pasquier, D. (2004). Cultures lycéennes. La tyrannie de la majorité, Autrement, Paris.

[65]. Pasquier, D. (2005). Cultures lycéennes. Éditions Autrement, Paris

[66]. Pronovost, G. (2000). Les jeunes et le temps, Lien social et Politiques, 43, 33-40.

[67]. Riesman, D., Glazer, N. \& Denney, R. (1955). The Lonely Crowd: A Study of the Changing American Character, Abridged and Revised Edition, Yale University Press, 2001

[68]. Rocher, G. (1970). Introduction à la sociologie, Tome 1, L'action sociale, Editions Seuil, Collection: Points essais, Paris.

[69]. Salvador, J. (2001). La société inhumaine, Paris, l'Harmattan.

[70]. Schutz, A. \&Luckmann T. (1973). The Structure of the Life World.Evanston, IL: Northwestern University Press.

[71]. Tavan, C. (2003). Les pratiques culturelles: rôle des habitudes prises dans l'enfance, ISSEE Première, $n^{\circ} 883$.

[72]. Tylor, E., (1871). Primitive culture, 2 Vol., in Nicolas Journet, Penser la culture, In revue Sciences Humaines, ${ }^{\circ} 110$, novembre 2000, pp.22-25.

[73]. Viira, R. \&Raudsepp, L. (2000). Achivement goal orientation, beliefs about sport soccer and sport emotions as elated to moderate to vigorous physical activity of adolescents. Psychology and Health, 15, 625-633

[74]. Wallon, H. (1990). Le jeu chez l'enfant. In E. Jalley \& L. Maury (éd.) Henri Wallon, écrits de 1926 à 1961 . Psychologie et dialectique (pp.148-164). Paris: Messidor. (Edition originale: 1949)

[75]. Zaffran, J. (2010). Le temps de l'adolescence, entre contrainte et liberté, Rennes, Presse universitaires de Rennes. 